Rakenteiden Mekaniikka (Journal of Structural Mechanics)

Vol. 50, No 3, 2017, pp. 341 - 344

https://rakenteidenmekaniikka.journal.fi/index

https://doi.org/10.23998/rm. 64916

(c) The author(s) 2017.

Open access under CC BY-SA 4.0 license.

\title{
Medium speed engine crankshaft analysis
}

\author{
Ilkka Väisänen ${ }^{1}$, Antti Mäntylä, Antti Korpela, Teemu Kuivaniemi and Tero Frondelius
}

Summary. This article describes the overview of crankshaft analysis of a medium speed diesel engine. Crankshaft analysis includes static analysis, crankshaft dynamics, bearing analysis, gear analysis, and stress \& fatigue analysis, the latter being in main focus in this article. AVL Excite Power unit is used for multibody dynamics and Abaqus for finite element analysis.

Key words: Wärtsilä, crankshaft, fatigue analysis, Findley algorithm

Received 15 June 2017. Accepted 18 August 2017. Published online 21 August 2017

\section{Introduction}

A crankshaft is a highly loaded component in a reciprocating internal combustion engine. To ensure the reliable function of this critical component, multiple types of analysis are carried out. The most common types are the static concept analysis, the dynamics stress and fatigue analysis and the closely related bearing [2], connecting rod [6] and fretting analysis [9]. The virtual engine crankshaft simulation methodology is presented in [3].

\section{Crankshaft dynamics}

Crankshaft dynamics calculation can be divided into a concept phase and advanced flexible multibody dynamic (MBD) simulations. Advanced flexible multibody dynamics simulations are able to capture transient and non-linear phenomenons. The crankshaft dynamics basic areas of interest are torsion and bending deformation as well as axial, main bearing and big end bearing forces.

The complete power train with crankshaft, connecting rods, intermediate gears, cam shafts, torsional vibration dampers and couplings are modeled with MBD software AVL Excite Power unit.

The crankshaft analysis process, see Figure 1, begins with the geometry of the power train components. The geometry is modified for finite element meshing using appropriate CAD software, in this case Siemens NX. Finite element (FE) model building is done by using prepossessing software like SimLab and HyperMesh, the SimLab being the preferred tool because of the easy automation of meshing processes and built-in tools for multibody model creation.

\footnotetext{
${ }^{1}$ Corresponding author. ilkka.vaisanen@gbw. fi
} 


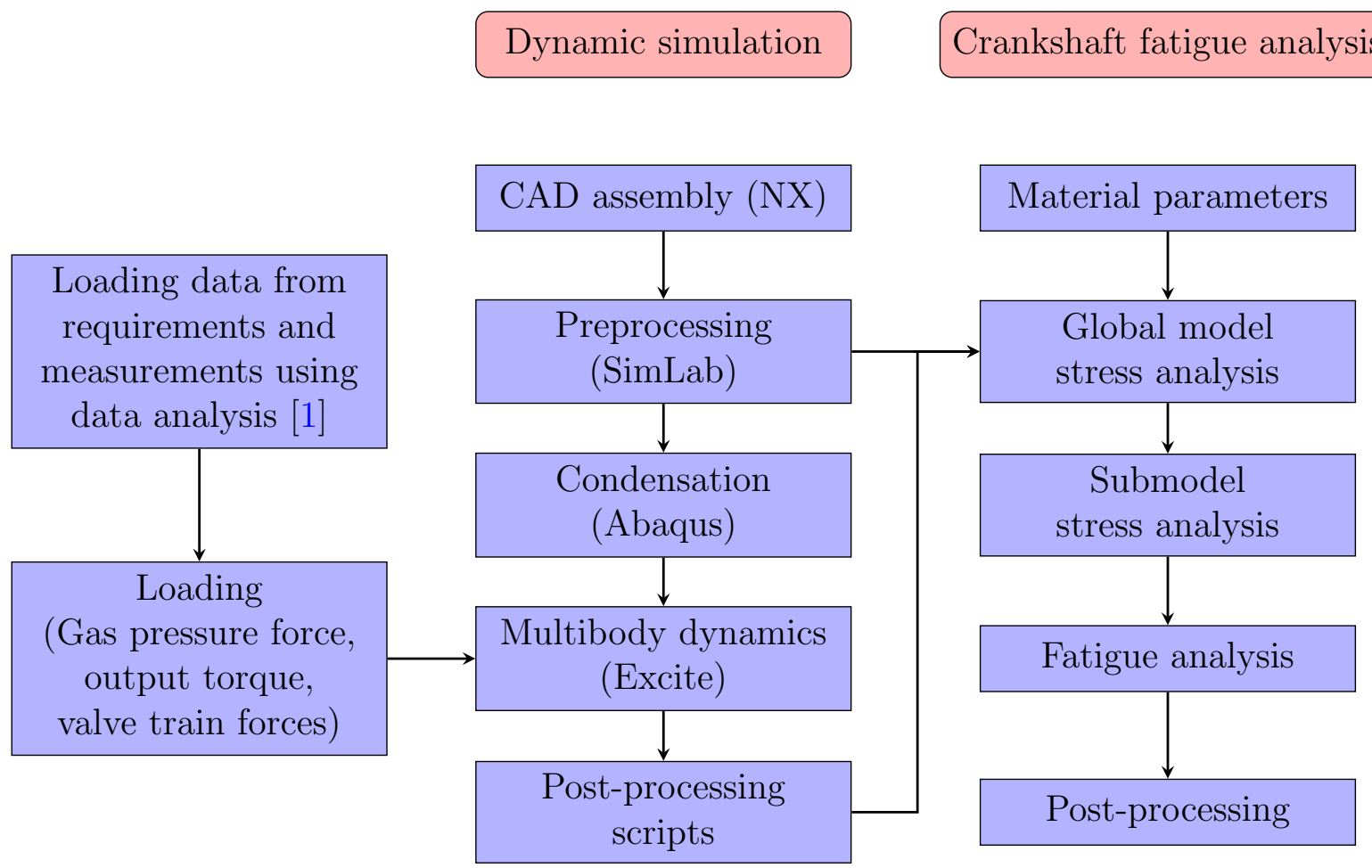

Figure 1. Crankshaft analysis flowchart

Condensation, see Figure 2, is done by running Abaqus analysis using preferably the Craig-Chang or Craig-Bampton sub-structuring methods [7]. The condensation method is explained more detail in [6].

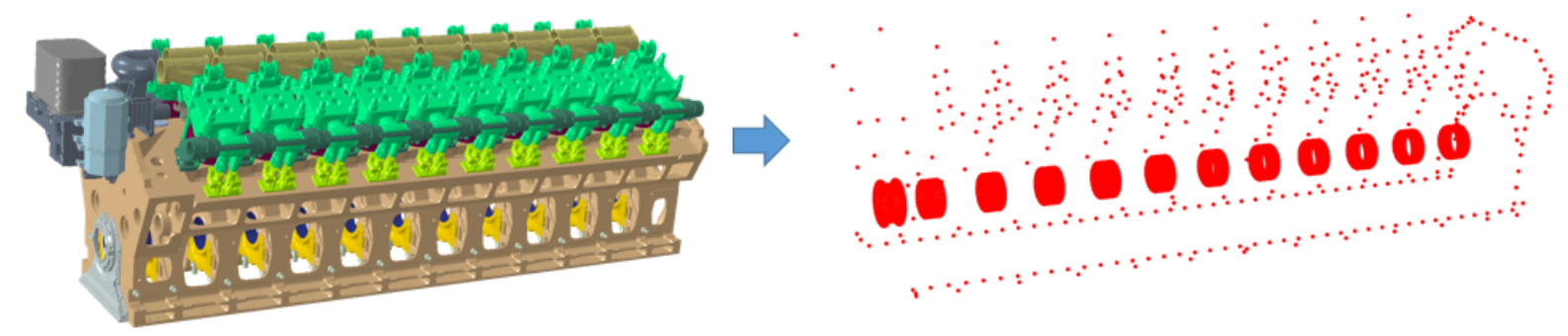

Figure 2. Engine block finite element model and retained degrees of freedoms

The MBD analysis is done with a suitable software package. The AVL Excite Power unit is capable of capturing all the required physical phenomena [5]. The MBD analysis is done in a time domain, using adaptive implicit time integration methods, mainly backward differentiation formulation (BDF) [4].

The MBD simulation is driven with external body loads, like gas forces, output torque, and valve train forces. Loads are derived from measurements or simulations. Data analysis is utilized to form representative load cases for engine lifetime usage. A detailed description of the data analysis is explained in [1].

Post-processing is done using a combination of the MBD software package, third-party software and in-house code. Most of the results generation is fully automatized. 


\section{Crankshaft fatigue analysis}

Crankshaft dynamics analysis results are used for calculating the crankshaft global stress state. Submodeling technique is used for accurate results in critical areas. Figure 3 shows a submodel of crankshaft main bearing fillet and a comparison of measured and simulated torsion.

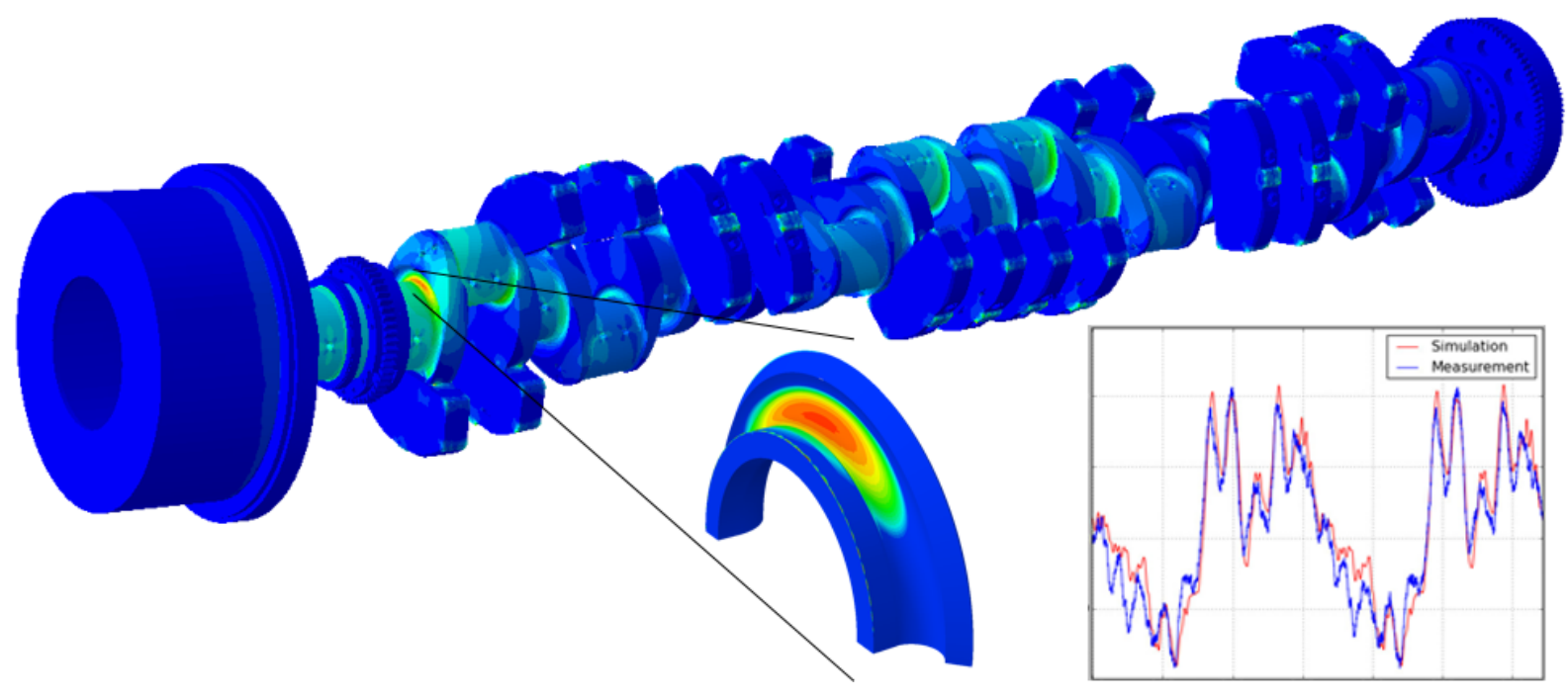

Figure 3. Crankshaft global stress, submodel of main bearing fillet with safety factor contour and comparison of measured \& simulated torsion

The purpose of crankshaft fatigue analysis is to produce information about the factor of safety and probability of failure. The analysis methods include fatigue criterion and fracture mechanics combined with probability theory. Material parameters are obtained from material testing. This is expained in [13].

The Findley criterion is one of the fatigue analysis methods used:

$$
\left(\frac{\Delta \tau}{2}+k_{f} \sigma_{n}\right)_{\max } \leq f
$$

where $\Delta \tau$ is the shear stress amplitude, $\sigma_{n}$ is the normal stress at critical plane, $k_{f}$ is a constant and $\mathrm{f}$ is the shear fatigue limit. The use of the Findley criterion is more closely explained in $[11,10,8]$.

Fracture mechanics is also used for crankshaft fatigue analysis. A good description of the application of Zcrack in crankshaft fatigue analysis is shown in [12].

\section{References}

[1] Jukka Aho and Tero Frondelius. Analyzing 3 TB field measurement data set. Rakenteiden Mekaniikka, 50(3):224-228, 2017. URL https://doi.org/10.23998/rm.64942.

[2] Liang Bai, Teemu Kuivaniemi, Pasi Halla-aho, and Tero Frondelius. Elasto hydro dynamic simulation of the slider bearing. Rakenteiden Mekaniikka, 50(3):283-286, 2017. URL https: //doi.org/10.23998/rm.64922.

[3] Tero Frondelius, Pasi Halla-aho, and Antti Mäntylä. Crankshaft development with virtual engine modelling. In CIMAC Congress Helsinki, 2016. 
[4] AVL List GmbH. Excite power unit theory. 2017.

[5] AVL List GmbH. Excite power unit user guide. 2017.

[6] Jussi Göös, Anton Leppänen, Antti Mäntylä, and Tero Frondelius. Large bore connecting rod simulations. Rakenteiden Mekaniikka, 50(3):275-278, 2017. URL https://doi.org/ $10.23998 / \mathrm{rm} .64658$.

[7] Antti Korpela. Thermal elasticity in flexible multibody simulation. Master's thesis, University of Oulu, 2012.

[8] Cristian Lonnqvist, Jan Kaas, and Roger Rabb. Comprehensive multiaxial fatigue analysis with abaqus. ABAQUS Users Conference, 2007. URL https://www.3ds.com/fileadmin/ PRODUCTS/SIMULIA/PDF/scc-papers/Comprehensive-Multiaxial-Fatigue-2007 .pdf.

[9] Antti Mäntylä, Jussi Göös, Anton Leppänen, and Tero Frondelius. Large bore engine connecting rod fretting analysis. Rakenteiden Mekaniikka, 50(3):239-243, 2017. URL https://doi.org/10.23998/rm.64914.

[10] Roger Rabb. Todennäköisyysteoriaan pohjautuva väsymisanalyysi. Books on demand, 2013. ISBN 978-952-286-210-5. pages 308-309.

[11] Roger Rabb, Christian Lonnqvist, and Jan Kaas. Multiaxial fatigue criteria applied to medium speed diesel engines. International Conference on multiaxial fatigue 85 fracture (ICMFF9), 2010. URL http://www . gruppofrattura.it/ocs/index.php/ICMFF/ICMFF9/ paper/viewFile/11840/11008.

[12] Joona Vaara, Antti Mäntylä, and Tero Frondelius. Brief review on high-cycle fatigue with focus on non-metallic inclusions and forming. Rakenteiden Mekaniikka, 50(3):146-152, 2017. URL https://doi.org/10.23998/rm.65048.

[13] Miikka Väntänen, Joona Vaara, Jukka Aho, Jukka Kemppainen, and Tero Frondelius. Bayesian sequential experimental design for fatigue tests. Rakenteiden Mekaniikka, 50(3): 201-205, 2017. URL https://doi.org/10.23998/rm.64924.

Ilkka Väisänen, Antti Korpela

Global Boiler Works Oy

Lumijoentie 8, 90400 Oulu

ilkka.vaisanen@gbw.fi, antti.korpela@gbw.fi

Antti Mäntylä, Teemu Kuivaniemi, Tero Frondelius

Wärtsilä

Järvikatu 2-4, 65100 Vaasa

antti.mantyla@wartsila.com, teemu.kuivaniemi@wartsila.com,

tero.frondelius@wartsila.com 